\title{
ECONOMIC ANALISYS OF A COFFEE-BANANA SYSTEM OF A FAMILY- BASED AGRICULTURE AT THE ATLANTIC FOREST ZONE, BRAZIL
}

\author{
Análise econômica de um sistema com cafeeiros e bananeiras em \\ agricultura familiar na Zona da Mata, Brasil
}

\author{
Elaine Ponciano Alves ${ }^{1}$, Márcio Lopes da Silva², Sílvio Nolasco de Oliveira Neto², \\ Tatiana Pires Barrella ${ }^{3}$, Ricardo Henrique Silva Santos ${ }^{4}$
}

\begin{abstract}
Agroforestry systems can reduce the risks of investing in just one crop. However, there are uncertainties like other agricultural and forestry activities. Therefore, there is the need for economic studies under conditions of economic risk of agroforestry systems. This work reports an analysis of the main components of costs and revenues of an agroforestry system with coffee and banana, as well as an analysis of its economic performance through indicators: net present value, equivalent period benefit (or cost), family labor revenue and a sensitivity analysis of net present value. The main cost components in the system are the human labor and mineral and organic fertilizers applied in coffee, and the costs for the production of coffee outweigh the costs of banana production. The monthly income from the production of bananas balances the costs of coffee production, generating a positive cash flow in the studied period. Financial indicators showed positive values, demonstrating the economic viability of the system with coffee and banana. The agroforestry system is economically feasible, even with variations of $\pm 20 \%$ in production costs and selling prices of their products. Variables that showed greater sensitivity on the net present value were the selling price of coffee and bananas, and the cost of coffee production.
\end{abstract}

Index terms: Musa spp; net present value; family labor revenue; sensitivity analysis.

\begin{abstract}
RESUMO
Os sistemas agroflorestais podem reduzir os riscos de investimento em uma só cultura, no entanto, apresentam incertezas como outras atividades agrícolas e florestais. Por isso, a necessidade de realizar estudos econômicos sob condições de risco ou de sensibilidade dos sistemas agroflorestais. Objetivou-se, neste estudo, determinar os principais componentes de custos e receitas de um sistema agroflorestal com cafeeiros e bananeiras, bem como analisar a rentabilidade econômica do sistema agroflorestal por meio dos indicadores: valor presente líquido, benefício (ou custo) período equivalente e remuneração da mão de obra familiar e a análise de sensibilidade, verificando o efeito no valor presente líquido. Observamos que os principais componentes de custos no sistema agroflorestal são a mão de obra e os adubos minerais e orgânicos aplicados nos cafeeiros, sendo que os custos para a produção do café são superiores aos da produção da banana. A receita mensal da produção das bananas equilibra os custos de produção cafeeira, gerando um fluxo de caixa positivo no período estudado. Os indicadores financeiros apresentaram valores positivos, demonstrando a viabilidade econômica do sistema agroflorestal com cafeeiros e bananeiras. O sistema agroflorestal é viável, economicamente, mesmo com variações de $\pm 20 \%$ nas variáveis de produção e venda de seus produtos. As variáveis que apresentaram maior sensibilidade no valor presente líquido foram o preço de venda do café e da banana, e o custo de produção cafeeira.
\end{abstract}

Termos para indexação: Musa spp.; valor presente líquido; receita da mão de obra familiar; análise de sensibilidade.

\section{INTRODUCTION}

Coffee family farmers worldwide struggle with the coffee prices volatility in conventional market (Bacon, 2004; Jena et al., 2012). Alternative models such as organic, fairtrade, specialty or certified coffee intend to reduce this vulnerability, but are reports of contradictory results on family farmers' economy (Bacon 2004; Jena et al., 2012; Kilian et al., 2006).
Coffee-based agroforestry systems (AFS) are associated with environmental resources conservation, less inputs needs and, a focus on both more sustainable production and generation other options of income for family farming (Coelli; Fleming, 2004; González; Perilla; Pulido, 2010; Perdoná et al., 2013).

Agroforestry systems represent an option of crops diversification, generating income and possibly contributing to food security of farmers (González; Perilla;

${ }^{1}$ Instituto Amazônia - Beruri - AM - Brasil

${ }^{2}$ Universidade Federal de Viçosa/UFV - Departamento de Engenharia Florestal/DEF - Viçosa - MG - Brasil

${ }^{3}$ Universidade Federal de Viçosa/UFV - Departamento de Educação/DPE - Viçosa - MG - Brasil

${ }^{4}$ Universidade Federal de Viçosa/UFV - Departamento de Fitotecnia/DFT - Campus Universitário - UFV - 36570-900 - Viçosa - MG - Brasil - rsantos@ufv.br

Received in july 16, 2014 and approved in january 20, 2015

Ciênc. Agrotec., Lavras, v.39, n.3, p.232-239, maio/jun., 2015 
Pulido, 2010; Souza; Graaff; Puleman, 2012). Smallholders rely on flexibility of their production systems, which comes from diversification of farming activities (Coelli; Fleming, 2004). In the Atlantic Forest region of Minas Gerais state, predominantly a hilly landscape, Arabica coffee is the major source of income for the family farming (Souza; Graaff; Puleman, 2012). In the Araponga County, there are few experiences of agroforestry, where family farmers are adapting the system to their needs, introducing native trees and fruit species, including banana (Souza et al., 2010).

The sustainability of family farming systems should be supported also by economic analysis, such as net present value, internal rate of return, benefit / cost ratio, payback period, remuneration of labor (Daniel et al., 2000; González; Perilla; Pulido, 2010). There are reports of coffee agroforestry systems with higher net income than coffee monocrop (González; Perilla; Pulido, 2010; Perdoná et al., 2013; Santos et al., 2000; Souza; Graaff; Puleman, 2012), and a trend to higher technical efficiency (Kilian et al., 2006), when considering other products besides coffee production. However, there are insufficient data on costs, revenues or economic indicators for coffee agroforestry systems either in the world (González; Perilla; Pulido, 2010; Kilian et al., 2006) or in the Atlantic Forest Region, Minas Gerais state, Brazil. These analyzes helps to evaluate the costs and benefits of production, and the formulation of recommendations of more advantageous and productive options (González; Perilla; Pulido, 2010; Rodrigues et al., 2007).

This paper is a case-study of a coffee and banana system. Analysis in this paper focuses on determining its main components of costs and revenues, as well as on analysis of its economic profitability and sensitivity of net present value.

\section{MATERIAL AND METHODS}

The study was carried out on a family farm located in the Atlantic Forest Region, Araponga County, Minas Gerais state, Brazil. The main economic activity of the family farm is the coffee crop, which is present in the region for 150 years (Araponga, 2012). The area of the study is part of a family owned farm, where each member has a plot for cultivation. The AFS occupies an area of 0.62 ha, with an average slope of $52 \%$ and approximate elevation of 905 m.a.s.l., located at $20^{\circ} 41^{\prime} \mathrm{S}, 42^{\circ} 32^{\prime} \mathrm{W}$, $130^{\circ}$ North to Southeast face.

The preservation of tree species among coffee (Coffea arabica L.) cv. Catuaí shrubs, and the planting of banana 'Prata' (Musa spp.) formed the system. There were 12 species of trees and shrubs. Most of the trees were native of Atlantic Forest Region and, known in the region by its common names: araticum (Annona crassiflora Mart.), capoeira-branca (Solanum macropus Dunal), cinco folhas (Zeyheria tuberculosa (Vell.) Bur), embaúba (Cecropia pachystachya Trécul.), fedegoso (Senna macranthera (DC. ex Collad.) H.S.Irwin \& Barneby), marmeleira (Machaerium stipitatum Voegl.), marianeira (Acnistus arborescens Schltdl.), papagaio (Aegiphila sellowiana Cham.) and pau-de-abóbora (not identified), but some exotic species are present (guandu (Cajanus cajan (L.) Millsp.); mamoeiro (Carica papaya L.) and mangueira (Mangifera indica L.). Fifty four tree individuals were recorded, $54 \%$ of them were capoeirabranca. The trees are not evenly spaced and do not receive any management. Moreover, all native Atlantic Forest species are protected by law and, although household usage of small amount is allowed, direct or indirect commercialization is prohibited and therefore did not enter the economic analysis. The farmer do not use the trees for any purposes and keeps them in the system aiming the reduction of direct sunlight incidence and help the coffee shrubs.

Most of coffee shrubs were planted in 1999 and pruned in 2006. In 2009, new shrubs of coffee 'Catuaí vermelho', 'Catucaí amarelo' and 'Catucaí vermelho' were planted between the rows of the older ones, totaling 2,250 plants. The row spacing is approximately $1.26 \mathrm{~m} \mathrm{x} 2.62$ $\mathrm{m}$. One hundred and twenty banana plants were planted in 2002. The AFS has no complete uniformity in relation to the spacing of the rows of coffee shrubs, banana trees and native trees that compose it.

The coffee shrubs were fertilized with mineral and organic inputs, and green manuring with jackbeans (Canavalia ensiformis (L.) DC.) planted between coffee lines. In the 2011/12 season were applied two organic fertilization with $2.5 \mathrm{~kg}$ of poultry litter per shrub and mineral fertilizer (150 g of NPK (20-05-20) per shrub), as well as micronutrients spraying (zinc sulfate, potassium chloride and boric acid). The banana trees did not receive any fertilizer. Mowing was eventually performed between the coffee lines. After every harvesting of the bunches, the banana trees had their leaves cut, leaving the pseudostem to go dry and not compete with other bananas until they could realize its final chopping. There have been two harvests of coffee berries, in order to pick a higher percentage of ripe berries in each one. The first harvest was handmade and the others were performed with the help of a coffee stripping machine.

The costs data for the economic evaluation consisted of labor, materials and machinery. The cost 
of deployment of the system and cost of land was not considered, once it affects drastically the economic performance of smallholdings (González; Perilla; Pulido, 2010). For data collection, the farmer and the system were visited fortnightly from October 2011 to May 2013. To consider two years of study, data were estimated for the months from June to October 2013, based on those achieved in the previous year. We recorded and quantified the following activities: services and hours of labor; applied inputs, machinery, production, and selling values. The prices used in the evaluation were those that the farmer actually paid or received for the input, activity and sales. All data correspond to the area of 0.62 hectares of the AFS.

Production variables used in this study are: bag of $60 \mathrm{~kg}$ of green coffee, weight of the banana fruits marketed, in $\mathrm{kg}$. Due to small quantities, it was not recorded the household consumption or losses. To obtain the income values, we used the prices actually paid to the farmer, $\mathrm{R} \$ 320.00$ per $60 \mathrm{~kg}$ bag of coffee and $\mathrm{R} \$ 0.90 \mathrm{a} \mathrm{kg}$ of banana. The income values considered the coffee crop in the years 2012 and 2013 and banana crop from October 2011 to October 2013.

After obtaining the field data, we created a cost and revenues flow of the AFS to determine the indicators of economic profitability and sensitivity analysis. The economic indicators evaluated were Net Present Value (NPV), Equivalent Period Benefit (Cost) - EPB(C), and Payment of Family Labor (PFL) as described below.

The NPV was calculated with the following formula (Equation 1):

$N P V=\Sigma_{j=0}^{n} \frac{R_{j}}{(1+i)^{j}}-\sum_{j=0}^{n} \frac{C_{j}}{(1+i)^{j}}$, where

$R j=$ Revenue $C j=$ costs $i=$ interest rate $j=$ period of time and, $n=$ number of compounding periods.

The hurdle rate (HR) was of $0.7 \%$ (a.m.), which correspond to return rate a little higher than savings accounts return in 2012/13. By this criterion, the activity is feasible if the NPV is positive.

The $\operatorname{EPB}(\mathrm{C})$ was calculated with the following formula (Equation 2):

$E P B(C)=\frac{N P V\left[(1+i)^{t}-1\right]}{1-(1+i)^{-n t}}$, where

$i=$ interest rate; $n=$ period of time; $t=$ number of compounding periods.
The project is considered economically viable if $\mathrm{EPB}(\mathrm{C})$ is positive, indicating that periodic benefits are greater than the periodic costs.

Payment of Family Labor (PFL) was estimated by the division of the Family Labor Revenue (FLR) by the number of labor days of work (LD) in the AFS (Equation 3). The Family Labor Revenue (FLR) was obtained by subtracting total costs (TC) from gross income (GI), except family labor, which is now paid by the residue.

$P F L=\frac{F L R}{L D}$ and,$F L R=G I-T C$, where

The farmer performed all human labor, without hiring outside labor. For analysis purposes, we used the value of $R \$ 35.00$, as reference, which was the market value of a working day in rural areas of the region. In Sensitivity Analysis, it was decided that the economic indicator analyzed would be NPV. The analysis based on $\mathrm{EPB}(\mathrm{C})$ would yield a similar result. Therefore, we varied the prices and costs of products (coffee and bananas) and interest rate within $\pm 20 \%$. Then we identified and sorted the variables that caused major changes in the NPV.

\section{RESULTS AND DISCUSSION}

The costs presented here are regarding only to the AFS production in two years (Table 1). The costs of land and the planting of the system are not included. For smallholdings the monetary value of products has a direct impact on total costs and taking the land value out of costs enhances the Internal Return Rate of coffee family enterprises up to 482.9\% (González; Perilla; Pulido, 2010). The labor in coffee crop is the main cost factor, accounting for $48 \%$ of total costs, followed by costs of inputs (28\%), related to fertilization with poultry manure, mineral fertilizer and micronutrient spray (Table 1). The cost of labor on banana plants accounted for $13 \%$ of total. The cost of production of banana is lower than that of coffee, as they correspond only to the fruit harvest service, cutting and thinning the pseudostems (Table 1).

Other study reports that the human labor either in coffee agroforestry (Souza; Graaff; Puleman, 2012) or conventional and organic (Siqueira; Souza; Ponciano, 2011) systems in the same region is the largest part of the cost as it is in other coffee production regions, where household labor is one of the most important input of family farmers (Coelli; Fleming, 2004). On those systems, coffee also requires most of services, especially in post-harvest activities and the input costs vary with the adopted management with the 
supplying of different amounts of fertilizer (Souza; Graaff; Puleman, 2012), depending mostly on coffee selling prices (Winter-Nelson; Temu, 2005).

Bananas require labor every month, but on coffee crop there is a concentration of labor demand in the months of May, June and July (Figure 1), the harvest season. In the months of October, January, February and March the labor regards fertilization of coffee. The mowing of weeds is sparse once shading reduces the growth of weeds.

Table 1: Composition of production costs of a family farming agroforestry system with coffee and banana in the period October 2011 to September 2013.

\begin{tabular}{|c|c|c|c|c|c|c|}
\hline \multicolumn{7}{|c|}{ COFFEE CROP } \\
\hline & Description & Unit & Unit Value $(\mathrm{R} \$)$ & Quantity (0.62 ha) & $\mathrm{R} \$ / 0.62$ ha & $\mathrm{R} \$ / \mathrm{ha}$ \\
\hline & Weed mowing & & & 2.72 & 95.24 & 153.62 \\
\hline & Side dressing & & & 5.23 & 183.05 & 295.24 \\
\hline & Spray & & & 3.44 & 120.40 & 194.19 \\
\hline & Gree manure planting & & & 1.07 & 37.41 & 60.33 \\
\hline \multirow[t]{9}{*}{ Labor } & $1^{\text {st }}$ harvest & Man/day & 35 & 35.49 & $1,242.15$ & $2,003.47$ \\
\hline & $2^{\text {nd }}$ harvest & & & 11.00 & 385.00 & 620.97 \\
\hline & Berry washing & & & 4.00 & 140.00 & 225.81 \\
\hline & Berry selection & & & 4.00 & 140.00 & 225.81 \\
\hline & Berry drying & & & 36.00 & $1,260.00$ & $2,032.26$ \\
\hline & Zinc Sulphate & & & & & \\
\hline & Boric Acid & $\mathrm{Kg}$ & 4.79 & 8.07 & 38.66 & 62.35 \\
\hline & Potassium Chloride & & & & & \\
\hline & Poultry manure & ton & 150 & 6.50 & 975.00 & $1,572.58$ \\
\hline \multirow[t]{6}{*}{ Inputs } & Mineral fertilizer (NPK) & $\mathrm{sc}$ & 62 & 17.04 & $1,056.48$ & $1,704.00$ \\
\hline & Jackbeans seed & $\mathrm{Kg}$ & 0 & 17.00 & 0.00 & 0.00 \\
\hline & Gasoline & $\mathrm{L}$ & 3 & 7.00 & 21.00 & 33.87 \\
\hline & Oil & $\mathrm{L}$ & 7 & 100.00 & 2.80 & 4.52 \\
\hline & Raffia bags & unit & 0.6 & 20.00 & 12.00 & 19.35 \\
\hline & Harvest internal transport & Freight & 25 & 4.00 & 100.00 & 161.29 \\
\hline \multirow[t]{2}{*}{ Machinery } & Mower & $\mathrm{h} /$ machine & 8 & 21.56 & 172.48 & 278.19 \\
\hline & Sprayer & $\mathrm{h} /$ machine & 7 & 27.50 & 192.50 & 310.48 \\
\hline Sub-total & & & & & $6,174.17$ & $9,958.33$ \\
\hline \multicolumn{7}{|c|}{ BANANA CROP } \\
\hline \multirow{3}{*}{ Labor } & Harvest, plummets selection & & & 12.32 & 431.16 & 695.42 \\
\hline & Pseudostem cut, leaf thinning & Man/day & 35 & 8.22 & 287.70 & 464.03 \\
\hline & Sprout thinning & & & 6.60 & 231.00 & 372.58 \\
\hline Machinery & Transport & Freight & 27.5 & 12 & 330.00 & 532.26 \\
\hline Sub-total & & & & & $1,279.86$ & $2,064.29$ \\
\hline TOTAL & & & & & $7,454.03$ & $12,022.62$ \\
\hline
\end{tabular}


The revenue from banana production in the AFS ( $R \$ 663.00)$ is distributed over the months, while revenue from coffee production is punctual (September), reaching $\mathrm{R} \$ 8,160.00$ (Figure 2). Some months had negative income values once the monthly revenue that comes from banana is smaller than the total costs, mainly from coffee production, which presents a punctual revenue. The months of May, June and July are the harvest period of the coffee and the farmer manages the system so that in this period the banana production decline, releasing labor for berry harvest. This complementarity between coffee and banana labor demand is a very important feature of the system. The smallholder's diversification in cash production allows farmers to manage activities in order to meet seasonal demands of labor throughout the year (Coelli; Fleming, 2004).

The coffee production in 0.62 ha was 9.5 bags of green coffee for the year 2012 and 16 bags 2013, equivalent to 15.6 bags and 25.8 bags per hectare, respectively.

The NPV, which is also considered investment income, for a hurdle rate of $0.7 \%$ per month over 24 months, was $\mathrm{R} \$ 6,375.01$. The $\mathrm{EPB}(\mathrm{C})$ was $\mathrm{R} \$ 289.49$ per month, which indicates that the periodic benefits are greater than the periodic costs, and represents the flow of monthly income.

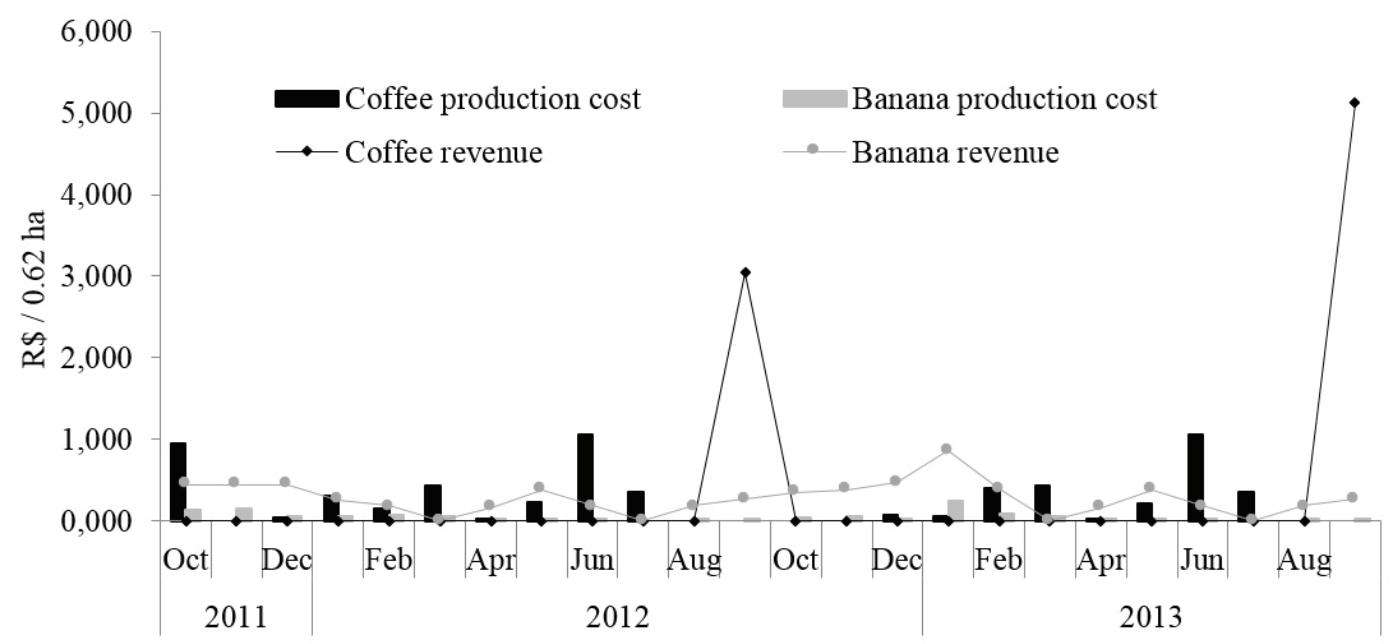

Figure 1: Annual distribution of labor (labor days) of a family farming agroforestry system with coffee and banana in the period October 2011 to September 2013.

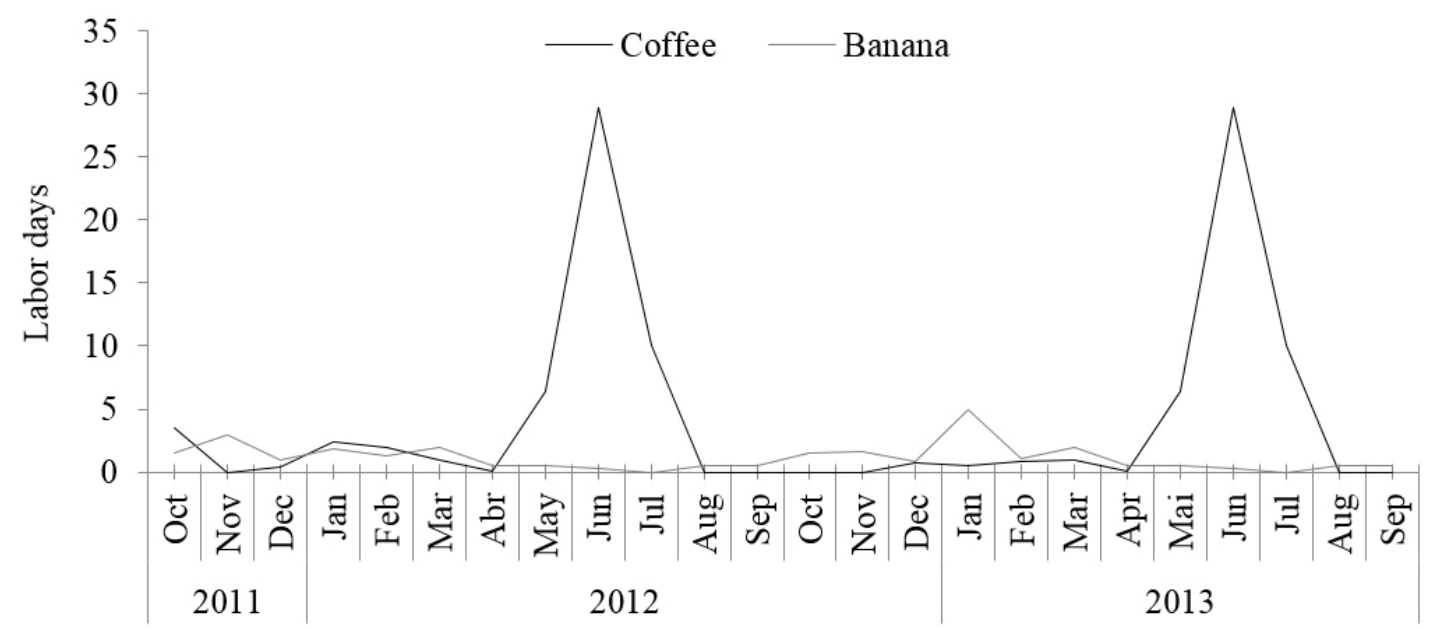

Figure 2: Flow of cost and revenue of the components of a family farming agroforestry system with coffee and banana in the period October 2011 to September 2013. 
The economic viability analysis of two monoculture coffee of low ( 25 bags ha $^{-1}$ ) or high yield ( 40 bags ha $^{-1}$ ) in Viçosa, Minas Gerais, Brazil reports positive NPVs with values of $\mathrm{R} \$ 997.76$ and $\mathrm{R} \$ 10,475.65$, respectively, considering a hurdle rate of $6 \%$ per annum (Arêdes; Pereira, 2008). There are reports of similar yield of coffee shrubs in monocrop or intercropped with banana (Pezzopane et al., 2007). Although one of these system present an overall low yield, it is similar to the Forest Region in Minas Gerais state average yield of 25.11 bags per hectare (CONAB 2013) but the system studied in our work presents both a low coffee yield and a higher NPV due to the presence of the banana crop.

Another economic study of an agroforestry system with coffee and 'bandarras' (Schizolobium amazonicum) in Ouro Preto do Oeste, Rondônia, Brazil, also found profitability. A coffee-macadania system presents a higher gross income than coffee monocrop (Perdoná et al., 2013). The profitability of agroforestry systems relates to intercropping species, crop management, inputs and market prices (Bentes-Gama et al., 2005; Rodrigues et. al., 2007). Considering that coffee and its inputs present constantly fluctuating prices, the diversification can be an alternative to reduce economic vulnerability of family farming in the region. Organic coffee in Brazil relies heavily its profitability on premium prices once it presents low technical efficiency (Siqueira; Souza; Ponciano, 2011). In addition, in the long run the growing supply of 'sustainable certificated coffee' (e.g. organic, fairtrade, forest friendly) will reduce price premiums (Killian et al., 2006) or the farmers will not actually receive this premium price (Bacon, 2005), while the diversification of coffee with another cash crop can economically support family farming (Coelli; Fleming, 2004; González; Perilla; Pulido, 2010).

The remuneration of family labor for the 130 days worked in AFS was calculated at $\mathrm{R} \$ 91.65$ per day, representing more than twice the opportunity cost of rural labor in the region. Therefore, it is more profitable for the farmer to work on this AFS than sell his labor. Either even with the change of $\pm 20 \%$ in the production cost of the coffee and banana, or in the selling prices, or the interest rate, there is a positive NPV (Figure 3) indicating that this AFS would be still economically viable. The variables that showed greater effect on the NPV were the selling prices of bananas and coffee and costs of coffee

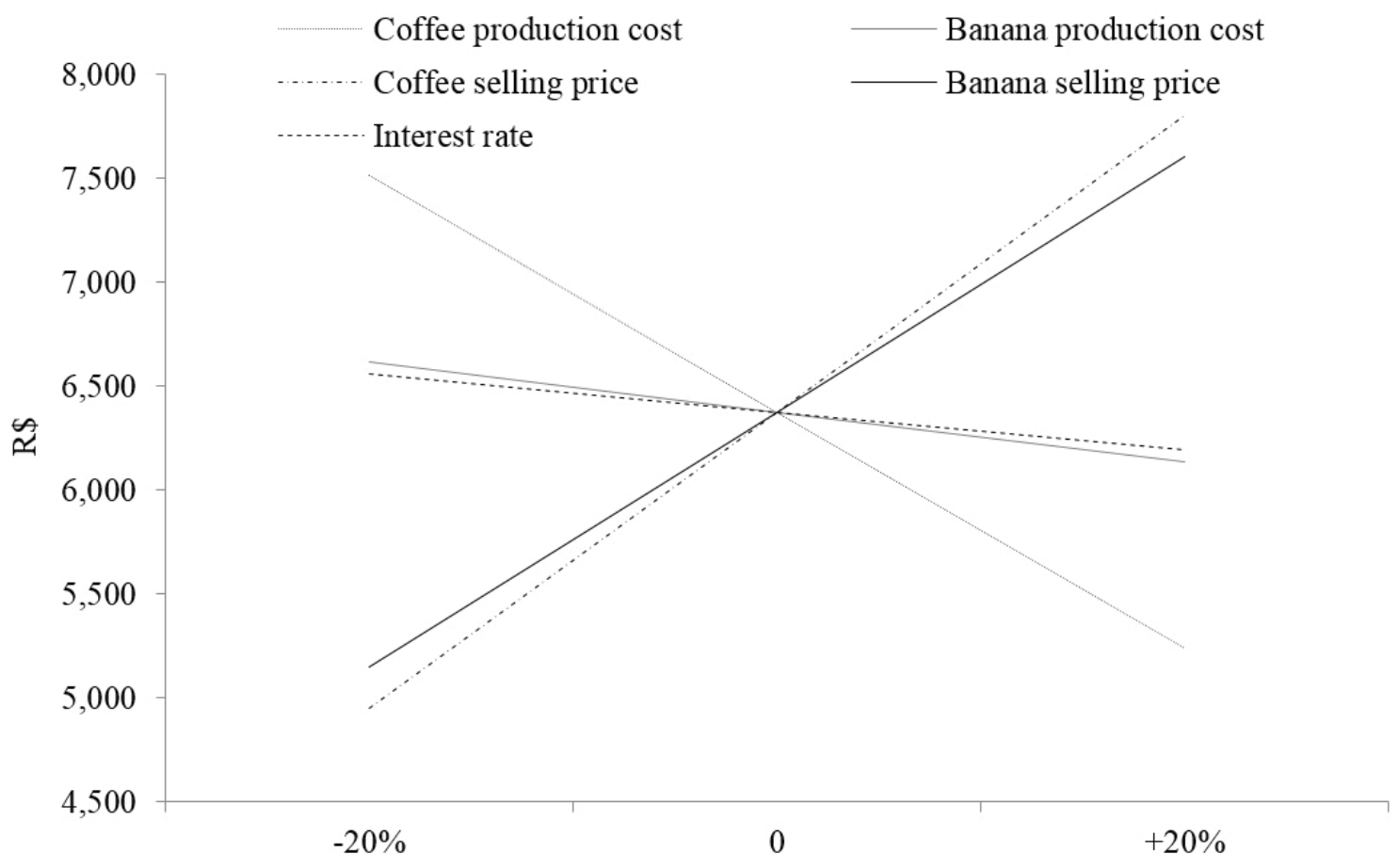

Figura 3: Sensitivity analysis of NPV considering variations between $20 \%$ and $-20 \%$ in the selling prices, production costs and, hurdle rate of a family farming agroforestry system with coffee and banana in the period October 2011 to September 2013. 
production. A sensitivity analysis of family farming coffee production in Colombia reports its vulnerability to coffee prices (González; Perilla; Pulido, 2010). Nevertheless, some authors claim that an increase the use of inputs is expected if there is an increase in coffee prices (WinterNelson; Temu, 2005).

Variations up to $-20 \%$ or $20 \%$ in the price of bananas and coffee lead to NPVs of similar values (Figure $3)$. Increases of $20 \%$ in production of coffee costs tends to reduce the NPV, but still the system would be economically viable. Variables that showed less effect on NPV were the interest rate and the cost of production of banana. The cost of production of banana has little effect as it is composed by labor and some freight delivery, not inputs being invested in its cultivation. The costs of keeping tree components intercropped with coffee is usually very low and has a positive impact on NPV and Internal Return rate, as reported for the Grevillea robusta - coffee systems in Parana state, Brazil (Santos et al., 2000) and a coffee-banana-Inga sp. systems in Colombia (González; Perilla; Pulido, 2010).

In relation to variations in selling prices of coffee and banana that override the NPV, the minimum selling price of bananas would be less than $\mathrm{R} \$ 0.00$ (zero) per $\mathrm{Kg}$, if the coffee is sold at $R \$ 320.00$ per bag. The minimum selling price for coffee would be $\mathrm{R} \$ 33.75$ per bag if the banana is sold at $\mathrm{R} \$ 0.90$ per $\mathrm{Kg}$.

Considering the minimum selling prices for the production of the AFS, a decrease in the price of coffee could be compensated by an increase in the production of bananas, an important feature of flexibility for family farmers, as reported for coffee family farmers in Papua New Guinea (Coelli; Fleming, 2004). The region is conducive to the production of tropical fruits (Bando; Silva, 2001) and banana plantations have one of the lowest economic risks for farmers (Vilela; Castro; Avellar, 2006).

The same comes for coffee i.e., increased plant yield by increasing inputs can be favorable for raising the economic return because revenues offset the increased costs caused by the increase in the use of inputs (WinterNelso; Temu, 2005; Arêdes; Pereira, 2008). However, as the selling price of coffee has much influence on the variation of NPV, and it is determined by the commodity market, coffee production in productive diversified systems becomes a protective mechanism for farmers against adverse price (Coelli; Fleming, 2005; González; Perilla; Pulido, 2010; Santos et al., 2000).

\section{CONCLUSIONS}

The main cost components in the agroforestry system are the human labor, mineral and organic fertilizers applied in coffee. Costs of coffee production are greater than the costs of production of bananas. Monthly revenue from banana production balances the costs of coffee production, generating a positive cash flow in the studied period. The financial indicators showed positive values, demonstrating the economic viability of this agroforestry system with coffee and banana. The AFS is economically feasible, even with variations of \pm $20 \%$ in production costs and selling prices their products. Variables that showed greater sensitivity on NPV were the selling price of coffee and bananas and, the cost of coffee production.

\section{REFERENCES}

\section{ARAPONGA. Prefeitura Municipal de Araponga.}

2012. Available in <http://www.araponga.mg.gov.br>. Access in: 02 jun. 2012.

ARÊDES, A. F.; PEREIRA, M. W. G. Análise econômica da produção de café arábica: um estudo de caso com simulações de Monte Carlo para sistemas de baixa e alta produtividade. Informações Econômicas. 38(4):19-30, 2008.

BANDO, P. M.; SILVA, C. A. B. Sistema agroindustrial de frutas na Zona da Mata Mineira: Agentes, organizações e ambiente institucional. Revista Ceres. 48(277):311-331, 2001.

BENTES-GAMA, M. M. et al. Análise econômica de sistemas agroflorestais na Amazônia Ocidental, Machadinho D'oeste- RO. Revista Árvore. 29(3):401411, 2005.

BACON, C. Confronting the coffee crisis: can fair trade, organic, and specialty coffees reduce small-scale farmer vulnerability in Northern Nicaragua? World Development. 33(3):497-511, 2005.

COELLI, T.; FLEMING, E. Diversification economies ans specialisation efficiencies in a mixed food and coffee smallholder farming system in Papua New Guinea. Agricultural Economics. 31:229-239, 2004.

CONAB - Companhia Nacional de Abastecimento. Acompanhamento da safra Brasileira: Safra 2013 segunda estimativa, maio/2013. Available in: <http://www.conab.gov.br/OlalaCMS/uploads/ arquivos/13_05_14_09_35_12 boletim_cafe maio_2013.pdf $>$ Access in: 12 mar. 2014. 
DANIEL, O. et al. Proposta de um conjunto mínimo de indicadores sócio-econômicos para o monitoramento da sustentabilidade em sistemas agroflorestais. Revista Árvore. 24(3):283-290, 2000.

GONZÁLEZ, W.; PERILLA, S. P.; PULIDO, A.

Análisis financiero del sistema de producción cafetalera en seis municipios de la provincia de Vélez (Santander, Colombia). Revista Colombiana de Ciências

Hortícolas. 4(2):235-242, 2010.

JENA, P. R. et al. The impact of coffee certification on small-scale producers' livelihoods: A case study from Jimma Zone, Ethiopia. Agricultural Economics. 43:429-440, 2012.

KILIAN, B. et al. Is sustainable agriculture a viable strategy to improve farm income in Central America? A case study on coffee. Journal of Business Research. 59:322-330, 2006.

PERDONÁ, M. J.; CRUZ, J. C. S.; FISCHER, I. H.; Cultivo consorciado de café e macadâmia. Pesquisa e Tecnologia. 10:1-6, 2013.

PEZZOPANE, J. R. et al. Avaliações fenológicas e agronômicas em café arábica cultivado a pleno sol e consorciado com banana 'Prata-anã'. Bragantia. 66(4):701-709, 2007.

RODRIGUES, E. R. et al. Avaliação Econômica de sistemas agroflorestais implantados para recuperação de Reserva Legal no pontal do
Paranapanema, São Paulo. Revista Árvore. 31(5): 941-948, 2007.

SANTOS, A. J. dos. et al. Viablidade econômica dos sistema agroflorestal Grevílea x Café na região norte do Paraná. Cerne. 6(1):89-100, 2000.

SIQUEIRA, H. M.; SOUZA, P. M.; PONCIANO, N. J. Café convencional versus café orgânico: Perspectiva de sustentabilidade socioeconômica dos agricultores familiares do Espírito Santo. Revista Ceres. 58(2):155160, 2011.

SOUZA, H. N. et al. Selection of native trees for intercropping with coffee in the Atlantic Rainforest biome. Agroforestry Systems. 80:1-16, 2010.

SOUZA, H. N.; GRAAFF, J.; PULLEMAN, M. M. Strategies and economics of farming systems with coffee in the Atlantic Rainforest Biome. Agroforestry Systems. 84:227-242, 2012.

VILELA, P. S.; CASTRO, C. W.; AVELLAR, S. $O$. C. Análise da oferta e da demanda de frutas selecionadas no Brasil para o decênio 2006/2015. Belo Horizonte: FAEMG, 2006. Available in: <http:// www.faemg.org.br/arquivos/ Análise da oferta demanda de frutas.pdf $>$. Access in: 25 apr. 2013.

WINTER-NELSON, A.; TEMU, A. Impacts of prices and transactions costs on input usage in a liberalizing economy: evidence from Tanzania coffee growers.

Agricultural Economics. 33:243-253, 2005. 